\title{
Modelling the habitat requirements of invasive Eastern Cottontail (Sylvilagus floridanus) introduced to Italy
}

\author{
Sandro Bertolino • Barbara Ingegno • Marco Girardello
}

Received: 20 November 2009 /Revised: 16 July 2010 / Accepted: 28 July 2010 /Published online: 10 August 2010

(C) Springer-Verlag 2010

\begin{abstract}
We analysed the spatial distribution of Eastern Cottontail (Sylvilagus floridanus) and its relationship with the habitat attributes of the agro-ecosystems in north-western Italy. We used generalised linear models to analyse the relationship between the occurrence of the cottontail and a series of landscape-level variables. Hierarchical partitioning was used to estimate the independent contribution of these variables. Our analysis showed that cottontail is typically a lowland species, in that it selected municipalities below $400 \mathrm{~m}$ a.s.l. and avoided higher elevations. Cottontails were more likely to occur where the edges of meadows and crop fields were higher. This might indicate the importance of these herbaceous habitats in cottontail feeding behaviour and also the significance of edge vegetation in providing cover. In addition, the extent of the hydrographic network positively affected cottontail presence, probably due to the permanent vegetation cover associated with the banks of rivers, streams and channels of the otherwise intensively cultivated and densely inhabited Po Plain. On the other hand, a prevalence of woodlands, tree plantations and large pastures negatively affected cottontail presence. This is surprising, because these habitats usually encourage cottontail presence in their native range. In general, however, cottontails prefer small woodlots
\end{abstract}

Communicated by C. Gortázar

S. Bertolino $(\bowtie) \cdot B$. Ingegno

DIVAPRA (Department of Protection and Exploitation

of Agricultural Resources),

Laboratory of Entomology and Zoology, University of Turin,

Via L. da Vinci 44,

10095 Grugliasco, TO, Italy

e-mail: sandro.bertolino@unito.it

M. Girardello

NERC Centre for Ecology and Hydrology,

Maclean Building, Benson Lane, Crowmarsh Gifford,

Oxfordshire OX10 8BB, UK and utilise only the edges of forests, while in Italy forests and pastures are large and typically located in hilly and mountain areas generally avoided by this species. In conclusion, our results confirm that the cottontail is an edge species whose presence is encouraged by crop margins, natural herbaceous habitats and extensive hydrographic networks with the associated riverside vegetation. These characteristics are common in the Po Plain and are likely to facilitate a further expansion of cottontail.

Keywords Introduced species · Lagomorph · Management · Species-habitat relationship

\section{Introduction}

The introduction of species is changing ecosystem composition and function (Ricciardi 2007). For this reason, the management of non-native species has become an important factor in wildlife and habitat conservation, as well as a priority for preserving human activities (Wittenberg and Cock 2001). The promotion of appropriate management strategies requires a deep understanding of the factors that either affect species distribution or abundance. This kind of information is generally derived either from intensive field work (Gurnell 1996; Bonesi and Macdonald 2003) or from habitat models (Barreto et al. 1998; Guisan and Zimmermann 2000; Tattoni et al. 2006; Bertolino et al. 2008). Model-based analyses of species-habitat relationships can help to clarify which factors influence the establishment and spread of non-native species (Bertolino and Ingegno 2009; Roura-Pascual et al. 2009). In turn, knowledge of the ecological requirements of these species is a prerequisite for the development of appropriate mitigation strategies (Braysher 1993; Bertolino et al. 2005). 
The Eastern Cottontail (Sylvilagus floridanus) is a lagomorph native to America and more precisely to southern Canada, USA, central and north-western South America (Chapman et al. 1980). The species was introduced to other areas of the USA (Chapman et al. 1980) and to several European countries (DAISIE 2009) for hunting purposes. As to date, wild populations in Europe that have survived are only located in Italy where the earliest introduction event dates back to 1966 (Mussa et al. 1996; DAISIE 2009). The species expanded its range eastward from the original area of introduction, across the Po Plain, mainly through the network of rivers which still retain some vegetation cover (Silvano et al. 2000; Vidus-Rosin et al. 2008). Nowadays, the species is present in a large area of north-western Italy that includes most of Piedmont and the western portion of Lombardy, while smaller populations are located in north-eastern and central regions of Italy (Angelici and Spagnesi 2008).

The cottontail is a possible vector of diseases that can be transmitted to native lagomorphs (Jacobson et al. 1978; Tizzani et al. 2002). In particular, it can be a carrier of pseudotuberculosis and myxomatosis. The former is transmissible to hares, which are prone to it, and the latter is lethal to the European rabbit (Oryctolagus cuniculus). Imported cottontails introduced to Italy have also introduced seven species of Eimeria, a genus of protozoan intestinal parasites of North American origins (Bertolino et al. 2010). Studies conducted in France and Italy have highlighted the risks connected to crop damage as well as those related to possible competition for food and space with other lagomorphs (Arthur and Chapuis 1983; Chapuis et al. 1985; Vidus-Rosin et al. 2008, 2009).

Cottontail habitat requirements in Italy have been investigated by means of field studies that included the observation of the animals (Vidus-Rosin et al. 2008, 2009), radiotracking (Bertolino et al. 2006) and pellet-plot counts (Vidus-Rosin et al. 2008). The main results of these local scale studies have shown a strong association of the species with herbaceous habitats and fallow lands. These two broad habitat categories comprise hedgerows and other shrubby habitats that provide permanent cover and small patches of cultivations that provide food supply. The aim of the present study was to analyse the spatial distribution of cottontail in relation to habitat attributes of agro-ecosystems at a large (regional) scale in an area where the cottontail was first introduced and that include most of the present range of the species.

\section{Methods}

Study area

The study area is Piedmont, a region in north-western Italy (Fig. 1). Piedmont can be divided into four main geographical areas: the Alps (with peaks above 1,500 m a.s.l.), the

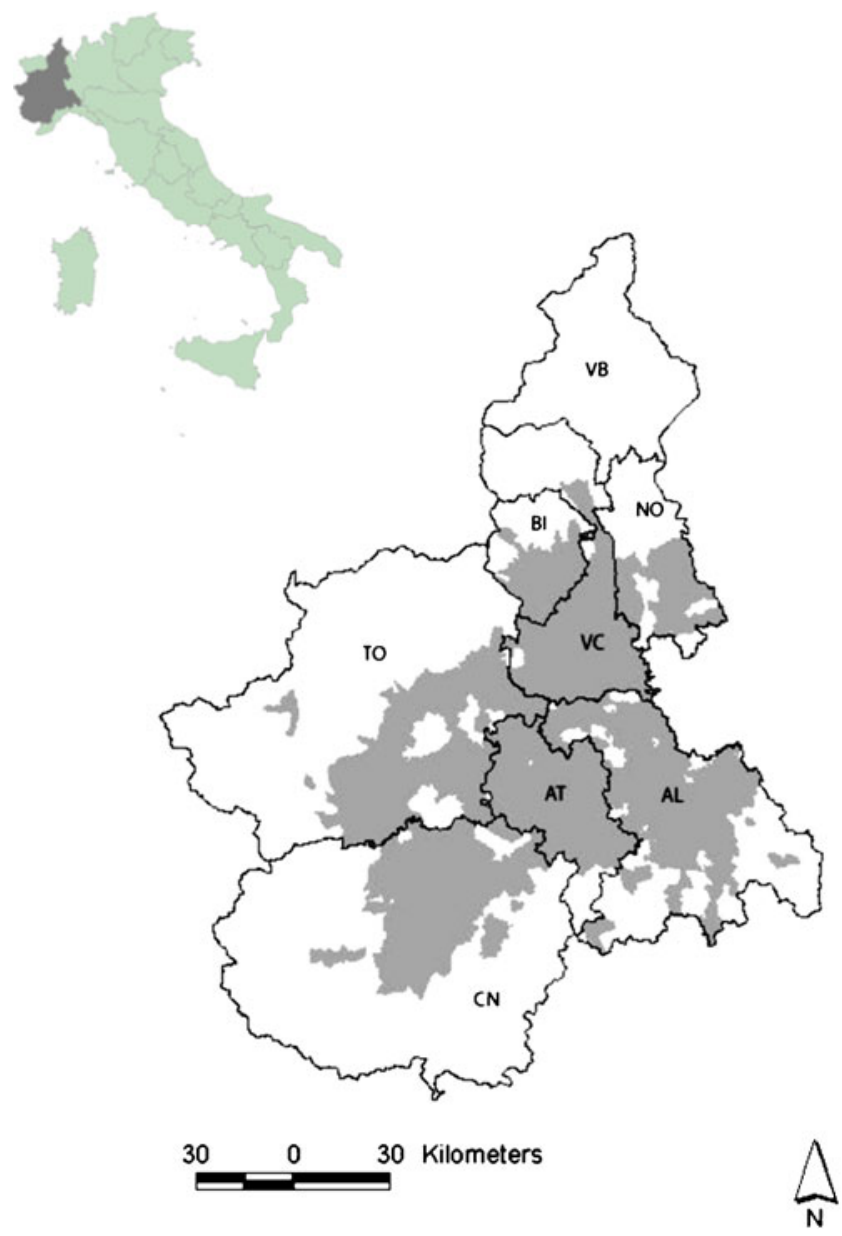

Fig. 1 Location of the Piedmont Region in Italy and its partition into eight provinces ( $A L$ Alessandria, $A T$ Asti, $B I$ Biella, $C N$ Cuneo, $N O$ Novara, $T O$ Torino, $V C$ Vercelli, $V B$ Verbania). The range of cottontail in 2002 is represented in grey. The map was produced joining the 467 municipalities where the species was present

pre-Alps (with peaks below 1,500 $\mathrm{m}$ a.s.1.), inland low hills and Apennines (the hills bordering the River Po, Monferrato, Langhe and Apennines uplands) and lowlands (including wide Alpine valley floors below $600 \mathrm{~m}$ a.s.1.). The total surface area is $25,383 \mathrm{~km}^{2}$, with $29 \%$ of lowlands and $71 \%$ of mountains and hills; $54 \%$ of the total is below $1,000 \mathrm{~m}$ of elevation (Gottero et al. 2007). At the time of the study, most of the region was covered by agricultural lands (37\%) and rangelands (13\%). Woodlands were mainly spread across the hilly areas, Alps and Apennines and almost absent from lowlands. They covered $34 \%$ of the surface. Urban areas comprised 1,209 municipalities (mean area 2,100 $\pm 2,299 \mathrm{ha}$ ), facilities and road infrastructures and covered $6 \%$ of the total surface (Gottero et al. 2007).

Habitat analysis

Measurements of landscape attributes were obtained from a CORINE (third level, scale 1:100,000) digital database with 
a resolution of $250 \mathrm{~m}$. Therefore, each $250-\mathrm{m}^{2}$-wide cell was characterised by one habitat type (predominant land cover type).

For each municipality considered in the analysis, we used 17 variables to describe the structure and composition of the landscape, thus focusing on those features that are relevant to the ecological requirements of cottontail (Table 1). We used ArcView 3.1 GIS software (ESRIEnvironmental Systems Research Institute, California) to assess the total surface area, the mean elevation and the length of the hydrographic network (elevation and hydrographic network source: Regione Piemonte website at http://www.regione.piemonte.it/repertorio). The landscape composition was assessed in terms of the relative proportions of the municipality's area covered by woodlands and tree plantations, open habitats, wetlands, crops and urban areas. The pattern and heterogeneity of the landscape mosaic were assessed using two indexes of patch characteristics, describing mean patch size and edge density (amount of edges in proportion to the relative area). These were calculated for each municipality and habitat category using the Patch Analyst extension of Arc View 3.1 (Table 1).

\section{Data analysis}

The distribution of the cottontails in 2000-2002 was mapped by compiling information provided by the Osservatorio Faunistico regionale (regional Wildlife Service) and the Wildlife Services of the provinces. The Osservatorio Faunistico regionale receives the data regarding the damage caused by wildlife within the region and is responsible for the collection of information on species presence. Further information was collected and made available by the staff of parks and protected areas, local hunting units, wildlife managers and scientists. Records of cottontails were collected at a municipality level, and we used only information derived from direct animal observations. The cottontail range in 2002 is reported in Fig. 1. The map was produced joining the 467 out of 1,209 municipalities where the species was present. The species distribution was modelled on a municipality scale.

The relationship between the presence of the cottontail and the independent variables was analysed by the means of a generalised linear model (GLM). Because there were no records of sites from which cottontails were surely absent, 467 further municipalities were selected at random throughout Piedmont following Stockwell and Peterson (2002). However, it is possible that some of the presumed absences are sites with cottontail, i.e. false negatives. In order to assess the impact of false negatives on the analysis, a false record permutation test (FRPT) was carried out (Greaves et al. 2006). The model was run with varying numbers of false absences and false presences; all sites and parameters were included. Initially, 437 of the presence sites were converted at random to false absences. This was carried out 50 times. This process was repeated, sequentially decreasing the number of false absences by ten, then increasing the number of false presences by ten until there were 437 false presences. Deviance explained $\left(D^{2}\right)$ values were used to assess the impact of this on model output. The Akaike information criterion (AIC) was used to select the minimum adequate model (MAM; Manel et al. 2001). Model selection was carried out using the stepAIC function from R package MASS (Venables and Ripley 2002). This
Table 1 Summary of explanatory variables (and their abbreviations) assessed for every municipality inside the study area

\begin{tabular}{ll}
\hline Variables & Description \\
\hline Hydrography & Hydrographic network size per surface unit (m/ha) \\
Urban \% & $\%$ of the surface covered by urban areas \\
Wetlands \% & $\%$ of the surface covered by wetlands \\
Woodlands \% & $\%$ of the surface covered by woodlands, orchards and tree plantations \\
Meadows \% & $\%$ of the surface covered by meadows \\
Pastures \% & $\%$ of the surface covered by pastures \\
Crops \% & $\%$ of the surface covered by crop fields (rice fields excluded) \\
PASTsize & Mean size of pastures (ha) \\
PASTedge & Amount of edge (perimeter of patches) of pastures relative to the area (m/ha) \\
MEADsize & Mean size of meadows (ha) \\
MEADedge & Amount of edge of meadows relative to the area (m/ha) \\
CROPsize & Mean size of crop (rice excluded) patches (ha) \\
CROPedge & Amount of edge of crops (rice excluded) relative to the area (m/ha) \\
WOODsize & Mean size of woodland patches (ha) \\
WOODedge & Amount of edge of woodlands relative to the area (m/ha) \\
TOTsize & Mean size of all patches (ha) \\
TOTedge & Amount of edge of all patches relative to the area (m) \\
\hline
\end{tabular}


function is a stepwise algorithm that sequentially searches through all possible models for the one that minimises the AIC. The stepwise search was performed both ways (i.e. backward and forward), as regular one-step approximations are considered less robust and less profitable (Venables and Ripley 2002). We finally estimated the significance of the parameters of our MAM using $z$ tests and evaluated the predicted performance of the final model using receiver operating characteristic (ROC) plot (Fielding and Bell 1997). Because no independent data were available for model validation, we used a tenfold cross-validation approach. A cross-validation is made with subsets of the training dataset, where each subset contains an equal number of randomly selected data points. Each subset is then dropped from the model, the model is recalculated and predictions were made for the omitted data points. A ROC plot was calculated for the output of the cross-validation. The discrimination ability of each of the ten random portions of data was assessed using the area under the curve (AUC; Fielding and Bell 1997). The AUC values range from 0.5 for models with no discrimination ability to 1 for models with perfect discrimination (Swets 1988).

We used hierarchical partitioning (HP) analyses to calculate the independent contribution of each predictor selected by the MAM. In HP all possible models for the distribution of a species are considered in a hierarchical regression setting. HP involves measuring the increase in the goodness-of-fit of all models with a particular variable compared with the equivalent model without that variable (Mac Nally and Horrocks 2002; Luoto et al. 2006; Radford and Bennett 2007). The improvement in fit is then averaged across all possible models in which that variable occurs to provide a measure of its independent effects. HP is considered superior to other multiple regression techniques for inferring probable causality in multivariate data sets (Watson and Peterson 1999). We specified a logistic model with log-likelihood as the goodness-of-fit measure.

To assess the degree of utilization of different elevation ranges by cottontail, we compared the observed frequency of the species at each elevation range (proportion of municipalities where cottontails were recorded, at each elevation range) with the expected values (proportion of municipalities at each elevation range) by means of the chisquare goodness-of-fit test and Bonferroni's confidence interval analysis (Neu et al. 1974; Manly et al. 2002).

All of the analyses were carried out in $\mathrm{R}$ version 2.9.2 ( $\mathrm{R}$ Development Core Team 2005).

\section{Results}

The 467 municipalities $(38.6 \%$ of the total) where the cottontail was recorded covered a surface of $9,421 \mathrm{~km}^{2}$
(37.1\% of the total surface). The proportion of municipalities where cottontails were recorded differed according to the province $\left(\chi^{2}=227, d f=7, P<0.001\right)$ : in the provinces of Asti, Vercelli, Alessandria, and Biella, the presence of cottontail was large, while in Verbania, the species was absent (Fig. 2). The species used municipalities below $400 \mathrm{~m}$ a.s.l. more than expected and avoided municipalities at higher elevations (Fig. 3).

The FRPT analysis carried out to assess the impact of using pseudo-absences in the model showed that the highest $D^{2}$ value was obtained when no false presences or false absences were included in the analysis. It was therefore justified to use the pseudo-absences in the analysis. The $D^{2}$ values for all combinations of false presences and absences included in the analysis are shown in Fig. 4.

Ten of seventeen environmental variables were retained in the minimum adequate model. The probability of cottontail occurrence was positively related to the amount of edge in crops and meadows, the hydrography extension, the mean size of meadow and pasture patches, and the mean size of all habitat patches contained within each municipality (Table 2). The variables related to the mean size of patches were selected in the model with coefficients close to zero; therefore, they probably did not really affect cottontail presence. Instead, cottontail presence was negatively related to the extension of municipalities covered by meadows, pastures, wetlands and woodlands. The crossvalidation exercise produced an AUC score of $0.92 \pm 0.02$ (mean \pm SD; Fig. 5).

The hierarchical partitioning analysis indicates that woodlands and hydrography brought the highest independent contribution in explaining cottontail presence (Fig. 6). A second group of variables were related to pastures cover, crops edges and pastures and all habitats sizes.

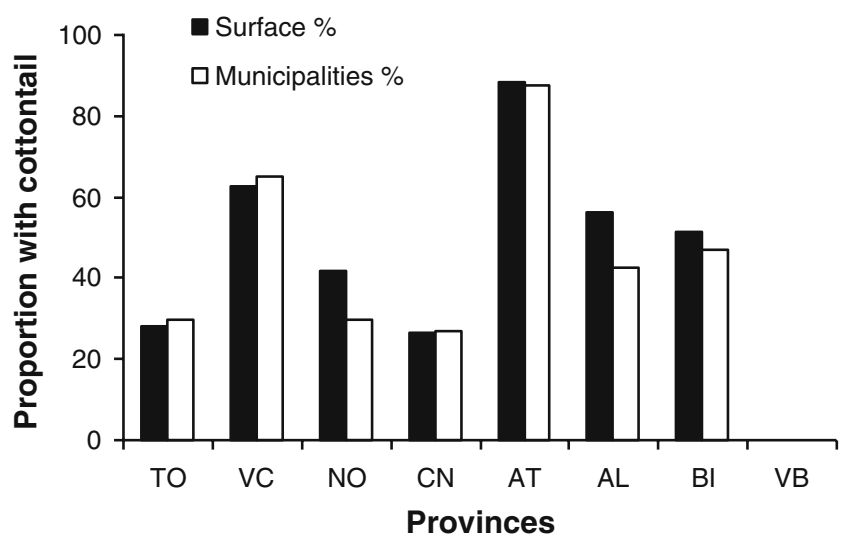

Fig. 2 Percentage of municipalities (number) and proportion of surface area with cottontail presence for each province. As for the proportion of surface, the areas of the municipalities in the province where cottontail was reported were summed and compared to the total surface area of the province. Symbols are explained in Fig. 1 


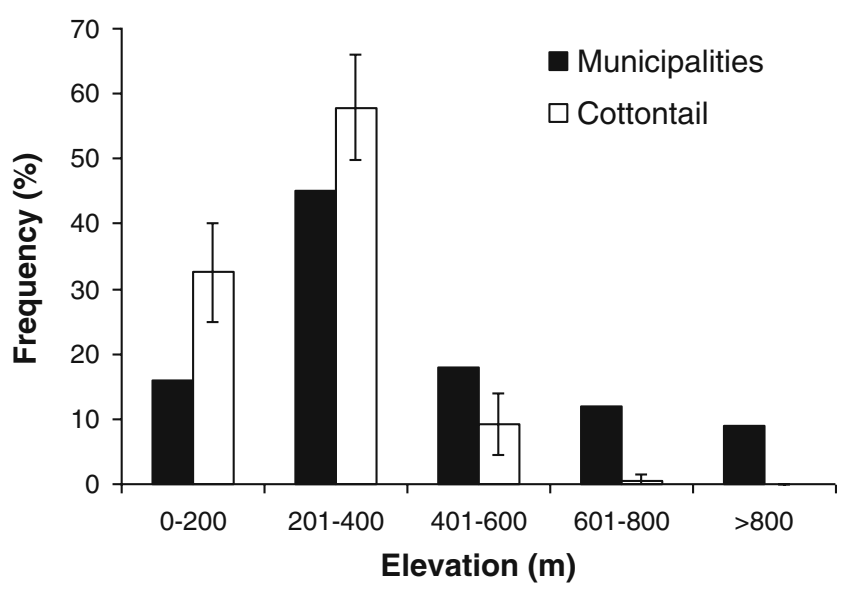

Fig. 3 Frequency of municipalities (black) and municipalities with presence of cottontail (white) at different elevation ranges. Bars indicate the Bonferroni's confidence intervals

\section{Discussion}

The present distribution of the Eastern Cottontail in Piedmont was modelled as a function of landscape attributes. The probability to find cottontails increased in municipalities where crops and meadows patches had a high perimeter/area ratio, i.e. a higher amount of edges, and an extensive hydrographic network. The mean size of meadows and pastures patches, as well as of all habitats patches, were positively related with the cottontail occurrence, but their effect was probably low. On the other hand, increasing the surface of municipalities covered by meadows and pastures, wetlands and woodlands, including tree plantations, had a negative effect.

The "edge" variables of open habitats such as crops and meadows that were retained in the minimum adequate model showed a positive effect on the species occurrence. This means that the extension of ecotones is more important



Fig. 4 The $D^{2}$ values of the GLM models produced as presences are gradually converted to false absences, then absences converted to false presences. The standard deviations are shown as error bars
Table 2 Minimum adequate model (MAM), based on stepwise AIC selection $\left(\mathrm{AIC}=647.41, D^{2}=0.52\right)$

\begin{tabular}{lrllrl}
\hline Variable & Coefficient & $d f$ & SE & \multicolumn{1}{l}{$z$} & $P$ \\
\hline CROPedge & 6.79 & 1 & 2.95 & 2.30 & 0.02 \\
Hydrography & 0.14 & 1 & 0.01 & 10.53 & 0.00 \\
MEADedge & 2.99 & 1 & 1.45 & 2.06 & 0.04 \\
Meadows & -8.10 & 1 & 2.76 & -2.94 & 0.00 \\
MEADsize & 0.01 & 1 & 0.00 & 2.09 & 0.04 \\
Pastures & -29.95 & 1 & 9.40 & -3.19 & 0.00 \\
PASTsize & 0.01 & 1 & 0.01 & 1.78 & 0.07 \\
TOTsize & 0.01 & 1 & 0.00 & 2.96 & 0.00 \\
Wetlands & -5.74 & 1 & 2.72 & -2.11 & 0.04 \\
Woodlands & -5.04 & 1 & 0.56 & -8.97 & 0.00 \\
\hline
\end{tabular}

than the overall surface covered by these habitats. An increase in the total surface of meadows in a municipality had a negative effect, while the probability of cottontail occurrence increased when meadows had a more convoluted shape (i.e. higher edge extension). Besides providing food, crops and meadows are often surrounded by residual of natural vegetation that may assure cover. According to Swihart and Yahner (1982), small patches of cultivations that are characterised by the growth of edges in proportion to the relative area may provide a source of food supply. In their native range, cottontail search areas with dense shrubs or other escape cover that is found near open foraging areas such as grasslands and pastures (Trent and Rongstad 1974; Althoff et al. 1997; Mankin and Warner 1999; Bond et al. 2002). A similar behaviour was observed also in Italy (Vidus-Rosin et al. 2008); in Piedmont, during night censuses, cottontails were mainly found in edge environments, between woody vegetation and open lands (Silvano et al. 2000).

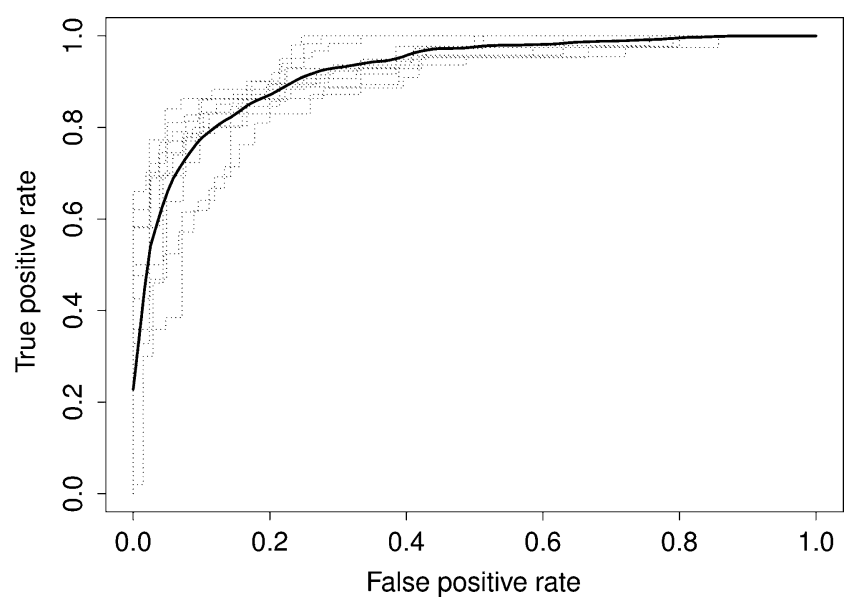

Fig. 5 ROC plot for the final model after the tenfold cross-validation. The dashed lines show the ROC curves calculated for each random partition of the cross-validation. The thick bold line shows the average ROC curve calculated across all the random partitions 


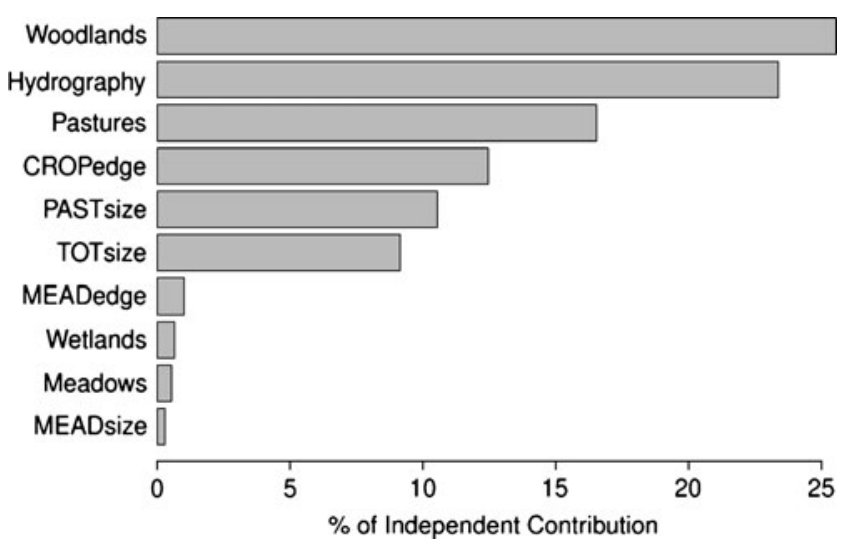

Fig. 6 Independent contribution for each of the ten variables selected in the MAM. Independent contribution was calculated using hierarchical partitioning (see text) and is expressed as the percentage of the independent contribution of each variable in explaining the total variance

The size of the hydrographic network positively affected the cottontail presence, while an increase in the surface covered by wetlands had a negative effect. The cottontail is not an aquatic species, but the extension of rivers and other basins resulted important for the species. This can be arguably explained by the presence of residual vegetation cover on the banks of the rivers of the heavily inhabited plain of Piedmont whose natural vegetation was drastically reduced by intensive cultivation. Other authors suggested that cottontails spread from their area of introduction by progressing through the river network of the Po Plain (Silvano et al. 2000; Vidus-Rosin et al. 2008).

The increase of pastures and woodlands negatively affected the likelihood of cottontail occurrence. Woodland cover in Piedmont is fragmented into small forests and tree plantations at low elevations while forms large forests at higher elevations, i.e. across hills and mountains. In Illinois, Mankin and Warner (1999) reported the extent of the decline of cottontail to be lesser in areas with more pastures, hay and woodlands. However, most of the woodlands were composed of fragmented woodlots and narrow riparian borders along rivers, interspersed with agricultural crops, thus suggesting that the cottontail is not so much a forest as an edge species (Mankin and Warner 1999). Beckwith (1954) observed that in abandoned fields, the number of cottontail decreases as succession proceeds towards a habitat with an increase in tree and canopy cover that usually accounts for a decrease in shrubby ground cover. In general, it seems that cottontail only enter either small woodlots or external portions of large forests and avoids their core (Beckwith 1954; Mankin and Warner 1999). On the contrary, pastures were found to be an important feeding habitat in North America (Trent and Rongstad 1974; Mankin and Warner 1999). The negative effect of pastures extension on the likelihood of cottontail occurrence in Piedmont may be explained by the fact that this habitat is mainly present in mountain areas, which are generally avoided by the cottontail. The cottontail proved to be a lowland species, in that it selected municipalities below $400 \mathrm{~m}$ a.s.l. and avoided higher elevations. On the other hand, pastures covered only a mean $( \pm \mathrm{SE})$ of 1.4 $(0.1) \%$ of the surface area of the municipalities below $600 \mathrm{~m}$ a.s.1., and a remarkable $14.3(11.3) \%$ at higher elevations (unequal variance $t$ test: $t=-24.44, p<0.001$ ).

Overall, cottontail resulted to be a lowland species, typical of open herbaceous habitats near vegetation that provides cover and the edges between cultivations and natural vegetation. Its presence is favoured by crops and meadows with high ecotones extension and wide hydrographic networks associated with riverside vegetation. Our results are in agreement with those reported by Vidus-Rosin et al. (2008) in their study at a local scale. These authors find cottontails in woody and row habitats, including field margins and hedgerows with herbs and woody layers along fields and streams. Thus, in Italy the cottontail has a pattern of habitat use that is similar to that reported in the agriculture-dominated portions of their native range, selecting habitats with dense and permanent cover near crops, meadows and other herbaceous habitats used for feeding (Chapman et al. 1980; Swihart and Yahner 1982). These characteristics are common in the Po Plain and may account for the increase in abundance distribution of the species during the last few decades (Angelici and Spagnesi 2008; Vidus-Rosin et al. 2008). In 20 years, the cottontail has expanded its range into north-western Italy (Vidus-Rosin et al. 2008). Populations in the province of Alessandria, for instance, have increased from a mean of 4.3 animals per 100 ha with peaks of 25-27 animals per 100 ha (Silvano et al. 2000) to 10-30 animals per 100 ha and a peak of 110 animals per 100 ha (Bertolino et al. unpublished data). Given the remarkable adaptability of this species, a further expansion eastwards in North Italy is likely to occur in the years to come and densities could probably increase further (Trent and Rongstad 1974; Chapman et al. 1980).

The cottontail is already widespread in northern Italy and any eradication programme should be presently considered unfeasible. Within this context, possible interactions with native hares should be carefully evaluated. Although first results suggest that the two species can coexist (VidusRosin et al. 2009, 2010; Bertolino et al. unpublished data), cottontail habitat requirement is partially similar to hares. Thus, further research is necessary to exclude a potential competitive advantage of the cottontail species in respect to the hare, under different environmental conditions.

Hare populations in agricultural landscapes are often to be found at low-density levels, and managers should consider management alternatives to improve habitat quality and increase population size. In this context, 
conservation measures have to improve native populations of hares while avoiding the introduction or expansion of non-native species. Our results may help to better plan landscape and habitat management for hare conservation. For instance, large meadows that usually favour hares (Hutchings and Harris 1996) turned out to have no or negative effects on cottontail presence. These habitats should therefore be the subject to improve farmland biodiversity in the areas where cottontails are present.

Acknowledgements We are grateful to the Osservatorio Faunistico del Piemonte, the provincial Wildlife Services and all the institutions and people that gave us information on the distribution of the cottontail in Piedmont. Two anonymous referees greatly improved a previous draft of the manuscript.

\section{References}

Althoff DP, Storm GL, Dewalle DR (1997) Daytime habitat selection by cottontails in central Pennsylvania. J Wildl Manage 61:450-459

Angelici FM, Spagnesi M (2008) Sylvilagus floridanus (JA Allen 1890). In: Amori G, Contoli L, Nappi A (eds) Mammalia II: Erinaceomorpha, Soricomorpha, Lagomorpha, Rodentia, vol 44, Fauna d'Italia. Edizioni Calderini e Il Sole 24 Ore, Milano, pp 305-313

Arthur CP, Chapuis JL (1983) L'introduction de Sylvilagus floridanus en France: historique, dangers et expérimentation en cours. CR Soc Biogéogr 59:333-356

Barreto GR, Rushton SP, Strachan R, Macdonald DW (1998) The role of habitat and mink predation in determining the status and distribution of water voles in England. Anim Cons 1:129-137

Beckwith SL (1954) Ecological succession on abandoned farmlands and its relationship to wildlife management. Ecol Monogr 24:349-376

Bertolino S, Ingegno B (2009) Modelling the distribution of an introduced species: the coypu Myocastor coypus (Mammalia, Rodentia) in Piedmont region, NW Italy. Ital J Zool 76:340-346

Bertolino S, Perrone A, Gola L (2005) Effectiviness of coypu control in small Italian wetland areas. Wildl Soc Bull 33:714-720

Bertolino S, Perrone A, Cordero di Montezemolo N, Gola L (2006) Progetto di ricerca sull'ecologia della Lepre comune (Lepus europaeus) e del Silvilago (Sylvilagus floridanus) in un'area di sovrapposizione spaziale nella Riserva Naturale del Torrente Orba. Wildlife Science and Parco del Po e dell'Orba (unpublished report)

Bertolino S, Lurz PWW, Sanderson R, Rushton S (2008) Predicting the spread of the American grey squirrel (Sciurus carolinensis) in Europe: a call for a co-ordinated European approach. Biol Cons 141:2564-2575

Bertolino S, Hofmannova L, Girardello M, Modry D (2010) Richness, origin and structure of an Eimeria community in a population of Eastern Cottontail (Sylvilagus floridanus) introduced into Italy. Parasitology 137:1179-1186

Bond BT, Burger LW Jr, Leopold BD, Jones JC, Godwin KD (2002) Habitat use by cottontail rabbits across multiple spatial scales in Mississippi. J Wildl Manag 66:1171-1178

Bonesi L, Macdonald D (2003) Evaluation of sign surveys as a way to estimate the relative abundance of mink. J Zool 262:65-72

Braysher M (1993) Managing vertebrate pests: principles and strategies. Australian Government Publishing Service, Canberra, Australia
Chapman JA, Hockman JG, Magaly M, Ojeda C (1980) Sylvilagus floridanus. Mammals Species 136:1-8

Chapuis JL, Forgeard F, Didillon MC (1985) Etude de Sylvilagus floridanus en region mediterraneenne dans des conditions de semi-liberte. Regime alimentaire au cours d'un cycle annuel par l'analyse micrographique des feces. Gibier Faune Savage 3:5-31

DAISIE-Delivering Alien Invasive Species Inventories for Europe (2009) Sylvilagus floridanus. In European Invasive Alien Species Gateway. Available via DIALOG. http://www.europe-aliens.org/ speciesFactsheet.do? speciesId=52904 of subordinate document. Accessed 30 Aug 2009

Fielding AH, Bell JF (1997) A review of methods for the assessment of prediction errors in conservation presence: absence models. Environ Cons 24:38-49

Gottero F, Ebone A, Terzuolo PG, Camerano P (2007) I boschi del Piemonte, conoscenze ed indirizzi gestionali. Blu edizioni, Regione Piemonte, Torino, Italy

Greaves RK, Sanderson RA, Rushton SP (2006) Predicting species occurrence using information-theoretic approaches and significance testing: an example of dormouse distribution in Cumbria, UK. Biol Cons 130:239-250

Gurnell J (1996) The effects of food availability and winter weather on the dynamics of a grey squirrel population in southern England. J Appl Ecol 33:325-338

Guisan A, Zimmermann NE (2000) Predictive habitat distribution models in ecology. Ecol Model 135:147-186

Hutchings MR, Harris S (1996) The current status of the brown hare (Lepus europaeus) in Britain. Joint Nature Conservation Committee, England

Jacobson HA, Kirkpatrik RL, McGinness BS (1978) Disease and physiologic characteristics of two cottontail populations in Virginia. Wildl Monog 60:1-53

Luoto M, Heikkinen RK, Pöyry J, Saarinen K (2006) Determinants of biogeographical distribution of butterflies in boreal regions. $\mathrm{J}$ Biog 33:1764-1778

Mac Nally R, Horrocks G (2002) Relative influences of patch, landscape and historical factors on birds in an Australian fragmented landscape. J Biog 29:395-410

Manel S, Williams HC, Ormerod SJ (2001) Evaluating presenceabsence models in ecology: the need to account for prevalence. J Appl Ecol 38:921-931

Mankin PC, Warner RE (1999) A regional model of the Eastern Cottontail and land-use changes in Illinois. J Wildl Manage 63:956-963

Manly BFJ, McDonald LL, Thomas DL, McDonald TL, Erickson WP (2002) Resource selection by animals. Kluwer Academic Publishers, The Netherlands

Mussa PP, Meineri G, Bassano B (1996) Il Silvilago in Provincia di Torino. Habitat 61:5-11

Neu CW, Byers CR, Peek JM (1974) A technique for analysis of utilization-availability data. J Wildl Manage 38:541-545

Radford JQ, Bennett AF (2007) The relative importance of landscape properties for woodland birds in agricultural environments. J Appl Ecol 44:737-747

R Development Core Team (2005) R: a language and environment for statistical computing. R Foundation for Statistical Computing, Vienna, Austria. http://www.R-project.org

Ricciardi A (2007) Are modern biological invasions an unprecedented form of global change? Cons Biol 21:329-336

Roura-Pascual N, Bas JM, Thuiller W, Hui C, Krug RM, Brotons L (2009) From introduction to equilibrium: reconstructing the invasive pathways of the Argentine ant in a Mediterranean region. Glob Change Biol 15:2101-2115

Silvano F, Acquarone C, Cucco M (2000) Distribution of the Eastern Cottontail Sylvilagus floridanus) in the province of Alessandria. Hystrix It J Mamm 12:75-78 
Stockwell DRB, Peterson AT (2002) Controlling Bias in Biodiversity Data. In: Scott JM, Heglund PJ, Morrison ML, Haufler JB, Raphael MG, Wall WA, Samson FB (eds) Predicting Species Occurrences. Issues of Accuracy and Scale, Island Press, Washington, pp 537-547 Swihart RK, Yahner RH (1982) Habitat feature influencing use of farmstead shelterbelts by the Eastern Cottontail Sylvilagus floridanus. Am Midl Nat 107:411-414

Swets KA (1988) Measuring the accuracy of diagnostic systems. Science 240:1285-1293

Tattoni C, Preatoni DG, Lurz PW, Rushton SP, Tosi G, Martinoli A, Bertolino S, Wauters LA (2006) Modelling the expansion of grey squirrels (Sciurus carolinensis) in Lombardy, Northern Italy: implications for squirrel control. Biol Invas 8:1605-1619

Tizzani P, Lavazza A, Capucci L, Meneguz PG (2002) Presence of infectious agents and parasites in wild populations of cottontail (Sylvilagus floridanus) and consideration on its role in the diffusion of pathogens infecting hares. In: European Association of Zoo and Wildlife Veterinarians (EAZWV) 4th scientific meeting, joint with the annual meeting of the European Wildlife Disease Association (EWDA), Heidelberg, Germany

Trent TT, Rongstad OR (1974) Home range and survival of cottontail rabbits in south-western Wisconsin. J Wildl Manage 38:459-472
Venables WN, Ripley BD (2002) Modern applied statistics with S, 4th edn. Springer, New York

Vidus-Rosin A, Gilio N, Meriggi A (2008) Introduced Lagomorphs as a threat to "native" Lagomorphs: The case of the Eastern Cottontail (Sylvilagus floridanus) in northern Italy. In: Alves PC, Ferrand N, Hackländer $\mathrm{H}$ (eds) Lagomorph Biology Evolution and Ecology and Conservation. Springer, Berlin, pp 153-165

Vidus-Rosin A, Montagna A, Meriggi A, Serrano Perez S (2009) Density and habitat requirements of sympatric hares and cottontails in northern Italy. Hystrix It J Mamm 20:101-110

Vidus-Rosin A, Lizier L, Meriggi A, Serrano Perez S, Fattorini L (2010) Habitat selection and segregation by two sympatric lagomorphs: the case of European hares and Eastern Cottontails in Northern Italy. VII Congresso Italiano di Teriologia, Hystrix It J Mamm Suppl 2010: 26

Watson DM, Peterson AT (1999) Determinants of diversity in a naturally fragmented landscape: humid montane forest avifaunas of Mesoamerica. Ecography 22:582-589

Wittenberg R, Cock MJW (2001) Invasive alien species: a toolkit of best prevention and management practices. CABI Publishing, Wallingford 